\title{
Potential recoverable natural gas resources in China
}

\author{
Liu Chenglin ${ }^{1 *}$, Zhu Jie ${ }^{2}$, Che Changbo ${ }^{2}$ and Liu Guangdi ${ }^{1}$ \\ ${ }^{1}$ School of Resource and Information, China University of Petroleum, Beijing 102249, China \\ ${ }^{2}$ Oil and Gas Resource Strategy Research Center of the Ministry of Land and resource, Beijing, China
}

\begin{abstract}
Natural gas resources in China are abundant. The undiscovered recoverable natural gas resources in China are estimated to be $19.27 \times 10^{12} \mathrm{~m}^{3}$. Natural gas is mainly distributed in the middle and west China and offshore areas of China. The Tarim Basin, Sichuan Basin, Ordos Basin, East China Sea Basin, Tsaidam Basin, Yinggehai Basin, and Qiongdongnan Basin are the main gas-bearing basins. The natural gas resources are not distributed evenly and are under-explored in China. The deeper horizons in east China, foreland basins and craton paleo-uplifts in the middle and west China, and the offshore basins are the main exploration areas in the future.
\end{abstract}

Key words: Natural gas, resources, exploration area, China

\section{Introduction}

The recoverable natural gas resources of China estimated by many researchers are generally $10 \times 10^{12}-14 \times 10^{12} \mathrm{~m}^{3}$ (Zhai, 2002; Shen et al, 2000; U.S. Geological Survey World Energy Assessment Team, 2000). A recent investigation on recovery rate of oil \& gas resources in the new round of national oil and gas resources assessment of China has made a significantly increased estimation of the potential recoverable natural gas resources, and the volume of the technically recoverable natural gas resources was estimated to be in the range of $15.4 \times 10^{12}-31.0 \times 10^{12} \mathrm{~m}^{3}$, with a mean of $22.0 \times$ $10^{12} \mathrm{~m}^{3}$, significantly higher than $12.75 \times 10^{12} \mathrm{~m}^{3}$, which was estimated in the second assessment of national oil and gas resources of China in 1994(Zhao et al, 2005; Zhang, 2004), and higher than $14 \times 10^{12} \mathrm{~m}^{3}$, which was estimated by China Academy of Engineering (2004).

\section{Distribution of undiscovered recoverable natural gas resources}

\subsection{Distribution in petroleum provinces}

Till 2004 year-end, the cumulative total recoverable natural gas reserves in China are $2.76 \times 10^{12} \mathrm{~m}^{3}$ (Shao et al, 2005), and the undiscovered recoverable natural gas resources are estimated to be $19.27 \times 10^{12} \mathrm{~m}^{3}$, which accounts for $87.6 \%$ of the total recoverable resources.

The distribution of the undiscovered recoverable natural gas resources is shown in Table 1, which shows that the undiscovered recoverable natural gas resources are mainly distributed in middle petroleum province, western petroleum province and offshore petroleum province, with a volume of $4.82 \times 10^{12} \mathrm{~m}^{3}, 6.76 \times 10^{12} \mathrm{~m}^{3}$ and $4.95 \times 10^{12} \mathrm{~m}^{3}$, respectively. At least $60 \%$ of the undiscovered recoverable natural gas resources are distributed in middle-west petroleum provinces,

*Corresponding author. e-mail: 1clzgx@126.com

Received February 28, 2007
$25.7 \%$ in offshore petroleum province and only $6.63 \%$ in eastern petroleum province.

\subsection{Distribution in basins}

As shown in Table 2, the undiscovered recoverable natural gas resources are mainly distributed in the following 7 basins: The Tarim Basin, the Sichuan Basin, the Ordos Basin, the East China Sea Basin, the Tsaidam Basin, the Yinggehai Basin and the Qiongdongnan Basin. The undiscovered recoverable natural gas resources of other 108 basins account for $24.0 \%$. The undiscovered recoverable natural gas resources in the Tarim Basin are the largest, with a volume of $5.40 \times 10^{12} \mathrm{~m}^{3}$ and account for $28.0 \%$ of the total undiscovered recoverable natural gas resources in China. The undiscovered recoverable natural gas resources in the Sichuan Basin, the Ordos Basin and the East China Sea Basin each account for more than $10 \%$.

\section{Main exploration areas}

In recent years, with the development of science and technology and the theory of hydrocarbon exploration and development, many big gas fields have been discovered, such as the Kela-2, Sulige and Puguang gas fields (Li et al, 2004; Song and Liu, 2006), showing good exploration prospect for gas resources in China. The deep formations in the eastern petroleum province, the foreland basins, craton paleo-uplifts and stratigraphic-lithologic traps in middle and western petroleum provinces, and the offshore basins, the QinghaiTibet Plateau, marine strata in the southern petroleum province and some under-explored basins are the main exploration areas for natural gas in the future (Fu et al, 2006; Jia and Chi, 2004; Wang, 2005).

\subsection{Deep formations in the eastern petroleum province}

As shown in Table 3, the volume of undiscovered recoverable natural gas resources in eastern petroleum 
Table 1 Distribution of the undiscovered recoverable natural gas resources in petroleum provinces

\begin{tabular}{cccc}
\hline Provinces & $\begin{array}{c}\text { Recoverable natural gas } \\
\text { resources } \\
\times 10^{12} \mathrm{~m}^{3}\end{array}$ & $\begin{array}{c}\text { Undiscovered recoverable } \\
\text { natural gas resources } \\
\times 10^{12} \mathrm{~m}^{3}\end{array}$ & $\begin{array}{c}\text { The ratio of the undiscovered } \\
\text { recoverable resources to the total } \\
\text { in China } \\
\%\end{array}$ \\
\hline Eastern & 1.47 & 1.28 & 6.63 \\
Middle & 6.37 & 4.82 & 24.99 \\
Western & 7.47 & 6.76 & 35.06 \\
Southern & 0.45 & 0.44 & 2.29 \\
Offshore & 5.26 & 4.95 & 25.70 \\
Qinghai-Tibet & 1.03 & 1.03 & 5.33 \\
\hline
\end{tabular}

Table 2 Distribution of the undiscovered recoverable natural gas resources in basins

\begin{tabular}{cccc}
\hline Basins & $\begin{array}{c}\text { Recoverable natural gas } \\
\text { resources } \\
\times 10^{12} \mathrm{~m}^{3}\end{array}$ & $\begin{array}{c}\text { Undiscovered recoverable natural } \\
\text { gas resources } \\
\times 10^{12} \mathrm{~m}^{3}\end{array}$ & $\begin{array}{c}\text { The ratio of the undiscovered } \\
\text { recoverable resources to the total } \\
\text { in China } \\
\%\end{array}$ \\
\hline Tarim & 5.87 & 5.40 & 28.0 \\
Sichuan & 3.42 & 2.75 & 14.3 \\
Ordos & 2.90 & 2.02 & 10.5 \\
East China Sea & 2.46 & 2.41 & 12.5 \\
Qaidam & 8.64 & 0.71 & 3.7 \\
Yinggehai & 0.81 & 0.71 & 3.7 \\
Qiongdongnan & 0.72 & 0.65 & 3.3 \\
\hline
\end{tabular}

province is $1.16 \times 10^{12} \mathrm{~m}^{3}$. The deep formations in the Songliao Basin and the Bohai Bay Basin are the most important exploration areas. Deep formations here refer to the new formations below the main producing formations. The volume of the undiscovered recoverable natural gas resources in these deep formations is estimated to be $0.94 \times 10^{12} \mathrm{~m}^{3}$, and only $3.2 \%$ of which has been discovered. The discovery of the Qingshen gas field shows great exploration potential of natural gas in the Songliao Basin (Zhai and He, 2005).

\subsection{Foreland basins and craton paleo-uplifts in middle-west China}

The volume of undiscovered recoverable natural gas resources in middle-west China is estimated to be $11.5 \times 10^{12}$ $\mathrm{m}^{3}$. The undiscovered recoverable natural gas resources are mainly distributed in the foreland basins, craton paleo-uplifts and stratigraphic-lithologic traps.

The foreland basins in middle-west China include the Kuqa Basin in Tarim, the southwest and southeast of the Tarim Basin, the northwestern and southern margins of the Junggar Basin, the western and northern margins of the Tsaidam Basin, the western Sichuan Basin, the Dabashan foreland and the Micangshan foreland of Sichuan Basin, and the west parts of the Ordos, Jiuxi and Tuha Basins (Jia et

Table 3 Distribution of undiscovered recoverable natural gas resources in eastern petroleum province

\begin{tabular}{ccccc}
\hline Fields & $\begin{array}{c}\text { Recoverable natural gas } \\
\text { reserves } \\
\times 10^{9} \mathrm{~m}^{3}\end{array}$ & $\begin{array}{c}\text { Recoverable natural } \\
\text { gas resources } \\
\times 10^{9} \mathrm{~m}^{3}\end{array}$ & $\begin{array}{c}\text { Undiscovered recoverable natural } \\
\text { gas resources } \\
\times 10^{9} \mathrm{~m}^{3}\end{array}$ & $\begin{array}{c}\text { Discovery rate } \\
\%\end{array}$ \\
\hline $\begin{array}{c}\text { Neogene } \\
\text { Deep } \\
\text { formations }\end{array}$ & 7.69 & 52.50 & 44.82 & 14.64 \\
Buried hills & 30.96 & 967.21 & 936.25 & 3.20 \\
Offshore & 11.96 & 116.31 & 108.36 & 6.84 \\
Total & 58.09 & 81.82 & 70.33 & 14.04 \\
\hline
\end{tabular}


Table 4 Distribution of undiscovered recoverable natural gas resources in the foreland basins in middle-west China

\begin{tabular}{|c|c|c|c|c|}
\hline Fields & $\begin{array}{c}\text { Recoverable natural gas } \\
\text { reserves } \\
\times 10^{9} \mathrm{~m}^{3}\end{array}$ & $\begin{array}{l}\text { Recoverable natural } \\
\text { gas resources } \\
\times 10^{9} \mathrm{~m}^{3}\end{array}$ & $\begin{array}{c}\text { Undiscovered recoverable } \\
\text { natural gas resources } \\
\times 10^{9} \mathrm{~m}^{3}\end{array}$ & $\begin{array}{c}\text { Discovery rate } \\
\%\end{array}$ \\
\hline Kuqa Basin & 287.68 & 2284.33 & 1996.65 & 12.59 \\
\hline $\begin{array}{c}\text { Southwest of Tarim } \\
\text { Basin }\end{array}$ & 27.15 & 1285.14 & 1258.00 & 2.11 \\
\hline $\begin{array}{c}\text { Southeast of Tarim } \\
\text { Basin }\end{array}$ & 0.00 & 114.02 & 114.02 & 0.00 \\
\hline $\begin{array}{c}\text { South of Zhungaer } \\
\text { Basin }\end{array}$ & 1.63 & 195.60 & 193.97 & 0.83 \\
\hline $\begin{array}{l}\text { Northwest of } \\
\text { Zhungaer Basin }\end{array}$ & 6.26 & 28.42 & 22.16 & 22.03 \\
\hline West of Qaidam Basin & 0.24 & 171.96 & 171.72 & 0.14 \\
\hline $\begin{array}{c}\text { North of Qaidam } \\
\text { Basin }\end{array}$ & 6.96 & 109.32 & 102.37 & 6.36 \\
\hline Tuha Basin & 25.28 & 139.66 & 114.38 & 18.10 \\
\hline Western Sichuan Basin & 86.32 & 672.85 & 586.53 & 12.83 \\
\hline Dabashan foreland & 20.37 & 526.60 & 506.23 & 3.87 \\
\hline Micangshan foreland & 0.00 & 60.49 & 60.49 & 0.00 \\
\hline West of Ordos Basin & 0.71 & 111.70 & 110.99 & 0.64 \\
\hline Total & 462.59 & 5700.10 & 5237.51 & 8.12 \\
\hline
\end{tabular}

al, 2005), with a total volume of undiscovered recoverable natural gas resources being $5.14 \times 10^{12} \mathrm{~m}^{3}$. The discovered gas fields in these areas are of large scale, high reserve abundance and high per-well production.

As shown in Table 5, there are many large paleo-uplifts in middle-west China, such as the Tabei paleo-uplift in northern Tarim, Leshan-Longnvsi paleo-uplift in the Sichuan Basin, Yimeng paleo-uplift in the Ordos Basin, Luliang paleo-uplift in the Junggar Basin, with a total volume of undiscovered recoverable natural gas resources of $2.80 \times 10^{12} \mathrm{~m}^{3}$. Especially, the volume of the undiscovered recoverable natural gas resources in the Tabei paleo-uplift, central paleo-uplift of the Tarim Basin and in the Kaijiang paleo-uplift of the Sichuan Basin is estimated to be more than $400 \times 10^{9} \mathrm{~m}^{3}$. These paleouplifts have favorable hydrocarbon accumulation factors and conditions to form large gas fields.

Table 5 Distribution of undiscovered recoverable natural gas resources in large paleo-uplifts in middle-west China

\begin{tabular}{|c|c|c|c|c|c|}
\hline & Fields & $\begin{array}{l}\text { Recoverable natural } \\
\text { gas reserves } \\
\times 10^{9} \mathrm{~m}^{3}\end{array}$ & $\begin{array}{l}\text { Recoverable natural } \\
\text { gas resources } \\
\times 10^{9} \mathrm{~m}^{3}\end{array}$ & $\begin{array}{l}\text { Undiscovered recoverable } \\
\text { natural gas resources } \\
\times 10^{9} \mathrm{~m}^{3}\end{array}$ & $\begin{array}{c}\text { Discovery rate } \\
\%\end{array}$ \\
\hline \multirow{2}{*}{$\begin{array}{l}\text { Tarim } \\
\text { Basin }\end{array}$} & Tabei paleo-uplift & 152.16 & 610.52 & 401.39 & 24.92 \\
\hline & Central paleo-uplift & 59.13 & 734.39 & 675.26 & 8.05 \\
\hline \multirow{3}{*}{$\begin{array}{c}\text { Sichuan } \\
\text { Basin }\end{array}$} & $\begin{array}{l}\text { Leshan-Longnvsi } \\
\text { paleo-uplift }\end{array}$ & 14.36 & 53.60 & 39.24 & 26.79 \\
\hline & Kaijiang paleo-uplift & 239.51 & 719.37 & 479.86 & 33.29 \\
\hline & Luzhou paleo-uplift & 17.32 & 55.55 & 38.23 & 31.18 \\
\hline \multirow{3}{*}{$\begin{array}{l}\text { Ordos } \\
\text { Basin }\end{array}$} & Central paleo-uplift & 189.50 & 478.91 & 289.41 & 39.57 \\
\hline & Yimeng paleo-uplift & 0.00 & 213.59 & 213.59 & 0.00 \\
\hline & Weibei paleo-uplift & 0.00 & 280.89 & 280.89 & 0.00 \\
\hline \multirow{3}{*}{$\begin{array}{l}\text { Jungar } \\
\text { Basin }\end{array}$} & Luliang paleo-uplift & 11.54 & 60.91 & 49.36 & 18.95 \\
\hline & Central paleo-uplift & 36.65 & 371.09 & 334.44 & 9.88 \\
\hline & Total & 720.17 & 3578.81 & 2801.68 & 20.12 \\
\hline
\end{tabular}




\subsection{Offshore basins}

The undiscovered recoverable natural gas resources are abundant in offshore basins in China, including the East China Sea basin, the Yinggehai basin, the Qiongdongnan basin and the Pearl River Mouth basin (Zhang, 2005; Xiao and Chen, 2003), with a volume of $4.95 \times 10^{12} \mathrm{~m}^{3}$. The big structural traps and stratigraphic-lithologic traps are the main exploration areas in the next 20 years.

\subsection{Under-explored basins}

The volume of undiscovered recoverable natural gas resources for 81 under-explored basins is estimated to be $1.76 \times 10^{12} \mathrm{~m}^{3}$ in the new round national oil and gas resources assessment of China. The undiscovered recoverable natural gas resources are mainly distributed in the Qiangtang Basin, the Changdu Basin, the Cuoqin Basin, the Biru Basin, the Chuxiong Basin and the Simao Basin, and the resources of each basin are more than $0.12 \times 10^{12} \mathrm{~m}^{3}$.

\section{Conclusions}

The results of the new round national oil and gas resources assessment of China suggest that the natural gas resources are abundant and could be found in 115 sedimentary basins. The volume of the recoverable natural gas resources is estimated to be $22.03 \times 10^{12} \mathrm{~m}^{3}$ and the discovery rate is only $12.6 \%$, showing great potential of natural gas resources in China. With the advance in exploration and development of natural gas, natural gas will be one of most important energy sources in the coming twenty to thirty years in China.

\section{References}

China Academy of Engineering. Research on sustainable supplying of China petroleum resources. April, 2004. Beijing (in Chinese)

Fu J H, Wei X S, Ren J F, et al. Gas exploration and developing prospect in Ordos Basin. Acta Petrolei Sinica. 2006. 27(6): 1-4 (in Chinese)

Jia C Z, Song Y and Wei G Q. Geological features and petroleum accumulation in the foreland basins in central and western China. Earth Science Frontiers. 2005. 12(3): 3-12 (in Chinese)

Jia C Z and Chi Y L. Resource Potential and Exploration Techniques of Stratigraphic and Subtle Reservoirs in China. Petroleum Science. 2004. 1(2): 1-12

Li J M, Liu S Z, Li, D X, et al. Exploratory situation and developmental trend of China's natural gas. Natural Gas Industry. 2004. 24(12): 1-4

Shen P P, Zhao W Z and Dou L R. Oil resources prospects and reserve forecast in China in next decade. Acta Petrolei Sinica. 2000. 21(4): 1-6 (in Chinese)

Song Y and Liu S. Exploration status and directions of gas exploration in China. Natural Gas Industry. 2006. 26(12): 20-25 (in Chinese)

U. S. Geological Survey World Energy Assessment Team. U.S. geological survey world petroleum system 2000-description and results. 2000

Wang T B. Main control factors of large and medium gas fields and exploration domains in China. Oil \& Gas Geology. 2005. 26(5): 572-583 (in Chinese)

Xiao G L and Chen J W. Natural gas exploration of offshore China. Marine Geology Letters. 2003. 19(8): 47-52 (in Chinese)

Zhai G M. Prospect of hydrocarbon resources of China in 21st century. Xinjiang Petroleum Geology. 2002. 23(4): 271-285 (in Chinese)

Zhai G M and He W Y. Regional structural background and China's oil and gas exploration orientation. China Petroleum Exploration. 2005. (2): 1-9 (in Chinese)

Zhang G C. Geological features and new exploration realms of offshore gas in China. China Offshore Oil and Gas. 2005. 17(5): 289-296 (in Chinese)

Zhao W Z, Wang Z C, Wang Z Y, et al. Progresses and significances of research on high-efficiency gas reservoir formation in China. Earth Science Frontiers. 2005. 12(4): 499-506 (in Chinese)

Zhang Y W. Potentials and Exploration Prospect of China's Hydrocarbon Resources, Petroleum Science. 2004. 1(1):1-7

(Edited by Zhu Xiuqin) 